\title{
Efforts to Increase Mathematical Learning Activity Material of Space Building Using Problem Posing Model Combination of Group Investigation and 3D Media
}

\author{
Darmiyati, Ratna Tiara \\ Elementary School Teacher Education \\ Universitas Lambung Mangkurat \\ Banjarmasin, Indonesia \\ darmiyati@ulm.ac.id
}

\begin{abstract}
This study aims to improve students' learning activities in mathematics regarding the nature of waking space using the problem-posing model combination group investigation and 3D media. This research was carried out at SDN Benua Anyar 4 Banjarmasin, Indonesia. Subjects in this study were 12th-grade students. The type of research used is class action research. Data collection used observation and tests. Based on the results of data analysis, there was an increase in student activity in learning where $91.67 \%$ of students were in active and very active qualifications. Learning outcomes also increased where evaluation of the classical completeness cycle I reached $50 \%$, $58 \%$ in the second cycle, $75 \%$ in the third cycle, and up to $91.67 \%$ in the IV cycle. It can be concluded that the application of problem posing models combined with group investigation and 3D media improves students' achievement and learning activities in mathematics.
\end{abstract}

Keywords-problem posing; group investigation; 3D Media; student activity; learning outcomes; mathematics

\section{INTRODUCTION}

The success of the learning process in mathematics subjects can be seen from the level of understanding, mastery of the material and the learning achievement of the students. But the reality that occurs in the field shows different things. At present many students still have difficulties in receiving the subject matter about the nature of space, there are still many of them who have not fully understood the concept of building space and its properties.

Based on the results of observation and interview with $5^{\text {th }}$ grade teachers, it was told that students had difficulties in identifying the nature of space in mathematics - the data of student learning outcomes in class V Benua Anyar 4 Elementary School in the last two years with the scores of 63 reinforced this fact. In 2015/2016, there were 14 of 29 students received a low grade or as much as $52 \%$ of students scored above the standard. In 2016/2017, there were 12 of 32 students scored below the standard or $63 \%$ of students scored above the standard.
These problems if left unchecked will have an impact on the students themselves; students will have learning difficulties and difficulty understanding mathematical concepts in the next lesson. In addition to having an impact on daily learning outcomes, students will also find it difficult to answer questions in general tests, because mathematical concepts are arranged systematically from the simple to the most complex. So that in this case to study mathematics, concepts that must be thoroughly understood before entering the next concept.

Learning without using learning media in explaining abstract mathematical material will make students difficult to understand the mathematical concepts. In mathematics learning requires aids in the form of teaching aids that can explain what is conveyed by the teacher so that it is more quickly understood and understood by students, this is done so that mathematics learning that is abstract can be brought in concrete conditions so that students more easily understand the lesson [1].

Learning models that can be used are very diverse in improving student learning activities in the material properties of space in class V SDN Benua Anyar 4 Banjarmasin. To increase the activity, and student learning outcomes when the learning process takes place using the Cooperative approach Learning and Problem Posing (PP) models combined Group Investigation (GI) using 3D Media.

According to [2] problem posing learning is learning that emphasizes on students to form/submit questions based on information or situation given. Information that is processed in mind and after being understood, students will be able to ask questions.

Ref [3] suggests that Group Investigation (GI) is a learning model that emphasizes student choice and control rather than applying teaching techniques in the classroom. Besides, it also combines the principles of democratic learning in which students are actively involved in learning activities, both from the beginning to the end of learning, including students having the freedom to choose the material to be studied by the topic discussed. 
This combination of learning models has an impact on students where there is an interaction between students, they are actively involved and can work together in solving the problems they face.

Researchers also complement using 3D media to help students understand abstract mathematical concepts to make it easier for students to receive material about the properties of space, by using media in mathematics learning activities is important, because the media can help students to understand the material abstract mathematics better. According to [4] that learning media is everything that is used to channel messages and can stimulate the mind, feelings, attention, and willingness of the learning so that it can encourage the learning process. By using 3D media in the learning of mathematics about the material properties of the building, space will help students to understand the concept and shape of space concretely.

The desire to know whether the use of models and research media used in this study can improve student activity and learning outcomes, it feels necessary to conduct research.

The problem solved in this research is, does the application of the Problem Posing Model Combination Groups Investigation and 3D Media can increase students' activities and learning outcomes in elementary school?

This research aims to find out the application of the Problem Posing learning model combination Groups Investigation and 3D Media can increase students' activities and learning outcomes in elementary school.

\section{MethOD}

The approach used in this study is a qualitative approach. According to reference [5] qualitative research is objectspecific research that cannot be examined statistically or qualitatively. Qualitative research produces descriptive data in the form of speech, writing, and behavior of the people observed. The type of research used is Classroom Action Research (CAR). According toreference [6], classroom action research is a form of reflective and collective research conducted by researchers in social situations to improve their social reasoning.

Actions applied in classroom action research are Stage I: Planning, Stage II: Implementation (Action) obeys what has been formulated in the action plan, but must also apply naturally. Stage III: Observation, Stage IV: Reflection Based on the results of this analysis the teacher reflects by reflecting or remembering and connecting events in class interactions, why they occur, and how the results are. The results of reflection will make the teacher aware of the level of success and failure that he achieved in corrective action.

Classroom action research (CAR) was carried out in class V SDN Benua Anyar 4 Banjarmasin in semester II 2017/2018 academic year with 12 students consisting of 7 male students and five female students. Researchers act as teachers, data collectors, and interpreters.

Data sources in this study are teacher data through observations of teaching activities in the classroom in applying the Problem Posing model combination Group Investigation and 3D Media.

Data sources are the teachers and students who are carrying out mathematics learning activities, using models and learning media.

The type of data presented in this study is qualitative and quantitative data. Qualitative data are data about teacher activities when conducting student learning and activities in group work. Quantitative data is data from the assessment through a written test carried out at the end of each meeting.

Indicators of the success of this study are the teacher's activities in carrying out learning activities are good, student activities are minimally active criteria, and classically reach $\% 82 \%$ of the number of students. The indicators of success for student learning outcomes in learning activities are when individual completeness of students reaches $\geq 63$, and for classical completeness reached $\geq 80 \%$ of students who received a score of $\geq 63$.

\section{RESUlTS AND DISCUSSION}

Based on the observations made by researchers on the activities of students in the learning process both in cycle I, cycle II, cycle III, and cycle IV there was an increase in activities where many students became more active in learning. Teachers also continue to experience improvement in teaching activities, as seen at the end of each cycle the teacher always reflects on the previous cycle and is taken to the next cycle so that learning can be better than the previous one.

After the teacher activities of the cycle I, II, III, and IV are done on the steps of learning activities; it can be concluded that the learning done has been done very well. Teacher activity in cycle I got a score of 28 which included in the criteria good. Then in cycle II got a score of 33 which is still included in the criteria of good. In Cycle III got a score of 39 which included very good criteria, and in the fourth cycle managed to increase the score to 44 with very good criteria. Thus, the teacher's activity has reached a predetermined success indicator, that is teacher activity can be said to be successful if the teacher gets a score in the implementation of the learning process with good criteria.

More clearly the results of observations of teacher activities in cycle I, II, III and IV

TABLE I. COMPARISON OF TEACHER ACTIVITY CYCLE I, II, III AND IV

\begin{tabular}{|l|c|c|c|c|}
\hline \multirow{2}{*}{$\begin{array}{c}\text { The overall } \\
\text { indicator } \\
\text { observed }\end{array}$} & \multicolumn{4}{|c|}{ Teacher Activity } \\
\cline { 2 - 5 } & $\begin{array}{c}\text { Cycle } \\
\boldsymbol{I}\end{array}$ & $\begin{array}{c}\text { Cycle } \\
\text { II }\end{array}$ & $\begin{array}{c}\text { Cycle } \\
\text { III }\end{array}$ & $\begin{array}{c}\text { Cycle } \\
\text { IV }\end{array}$ \\
\hline Total Score & 59,57 & 70,21 & 82,97 & 93,61 \\
\hline Criteria & $\begin{array}{c}\text { Pretty } \\
\text { Good }\end{array}$ & Good & $\begin{array}{c}\text { Very } \\
\text { Good }\end{array}$ & $\begin{array}{c}\text { Very } \\
\text { Good }\end{array}$ \\
\hline
\end{tabular}

More details can be seen in the graph below: 


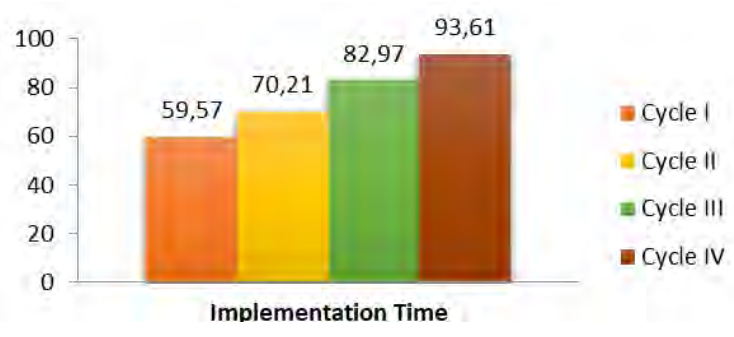

Fig. 1. Comparison of Teacher Scores

From the table and chart above it can be seen that the teacher always experiences an increase for each cycle. The teacher makes improvements for each cycle, the teacher reflects the learning at the end of each cycle, and the reflections that have been carried out are taken to the next cycle so that learning becomes more optimal so that the learning process can be better.

In addition to teacher activities that are always increasing, there is also an increase in student activity in each cycle.

From the beginning of the first cycle to the fourth cycle, students always experience an increase because students begin to familiarize themselves with the learning model implemented by the teacher, besides the teacher who keeps trying to guide students, the students themselves also build knowledge in addition to what has been conveyed by the teacher. The results of observations of student activities on learning activities in cycles I, II, III and IV can be seen in the table below:

TABLE II. COMPARISON OF STUDENT ACTIVITY CYCLE I, II, III AND IV

\begin{tabular}{|l|l|l|l|l|l|l|l|l|}
\hline \multirow{2}{*}{ Criteria } & \multicolumn{2}{|c|}{ Cycle I } & \multicolumn{2}{c|}{ Cycle II } & \multicolumn{2}{c|}{ Cycle III } & \multicolumn{2}{c|}{ Cycle IV } \\
\cline { 2 - 9 } & $\boldsymbol{S}$ & $\boldsymbol{P}$ & $\boldsymbol{S}$ & \multicolumn{1}{c|}{$\boldsymbol{P}$} & $\boldsymbol{S}$ & \multicolumn{1}{|c|}{$\boldsymbol{S}$} & $\boldsymbol{S}$ & \multicolumn{1}{c|}{$\boldsymbol{P}$} \\
\hline Very Active & 3 & $25 \%$ & 5 & $41.67 \%$ & 6 & $50 \%$ & 6 & $50 \%$ \\
\hline Active & 2 & $16.67 \%$ & 3 & $25 \%$ & 3 & $25 \%$ & 5 & $41.67 \%$ \\
\hline Quite Active & 4 & $33.33 \%$ & 4 & $33.33 \%$ & 3 & $25 \%$ & 1 & $8.33 \%$ \\
\hline Less Active & 3 & $25 \%$ & 0 & $0 \%$ & 0 & $0 \%$ & 0 & $0 \%$ \\
\hline Amount & 12 & $100 \%$ & 12 & $100 \%$ & 12 & $100 \%$ & 12 & $100 \%$ \\
\hline
\end{tabular}

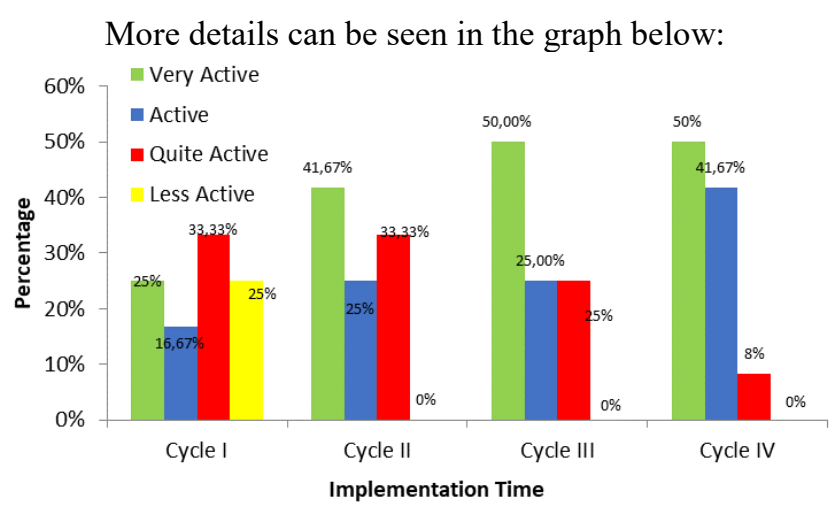

Fig. 2. Comparison of Student Activities Cycle I, II, III and IV

Based on the tables and images of observations of student activities can be known students who are in the criteria of inactive there are three people or $25 \%$ in the first cycle, but there are no cycles II, III, and IV or $0 \%$. Students who are on the criteria are quite active in the first cycle there are four people or $33.33 \%$, and in the second cycle, there are also four people or $33.33 \%$, in the third cycle there are three people or $25 \%$, and in the IV cycle there is one person or $8.33 \%$. Students who are in the active criteria at cycle I are two people or $16.67 \%$, and in cycle II there are three people or $25 \%$, in cycle III there are three people or $25 \%$, in cycle IV there are five people or $41.67 \%$. Students who are on the criteria of very active in the first cycle there are three people or $25 \%$, and in the second cycle there are five people or $41.67 \%$, in the third cycle there are six people or $50 \%$, then in the IV cycle, there are six people or $50 \%$. So, students who get very active and active information in the first cycle are 5 people with a classical percentage of $41.67 \%$, in the second cycle as many as 8 people with a classical percentage of $66.67 \%$, in the third cycle as many as 9 people with classical percentage is $75 \%$, and in cycle IV is 11 people with a classical percentage of $91.67 \%$.

It can be concluded that the IV cycle has increased student activity from cycles I, II, and III. Thus the activity of students has reached a predetermined success indicator, namely student activity is said to be successful if students individually achieve minimum active criteria and classically reach $\geq 82 \%$ of the number of students with very active and active criteria. It has even exceeded the expected indicators of success.

While for student learning outcomes based on tests carried out at the end of learning consisting of cycles I, II, III, and IV obtained value data to find out how student learning outcomes in cycles I, II, III, and IV can be seen in the table below.

TABLE III. COMPARISON OF INDIVIDUAL LEARNING OUTCOMES CYCLE I, II, III AND IV

\begin{tabular}{|l|l|l|l|l|}
\hline \multirow{2}{*}{ Cycle } & \multicolumn{4}{|c|}{ Student Completeness } \\
\cline { 2 - 5 } & Complete & Percentage & Not Complete & Percentage \\
\hline I & 6 & $50 \%$ & 6 & $50 \%$ \\
\hline II & 7 & $58,33 \%$ & 5 & $41.67 \%$ \\
\hline III & 9 & $75 \%$ & 3 & $25 \%$ \\
\hline IV & 11 & $91,67 \%$ & 1 & $8.33 \%$ \\
\hline
\end{tabular}

More details can be seen in the graph below:

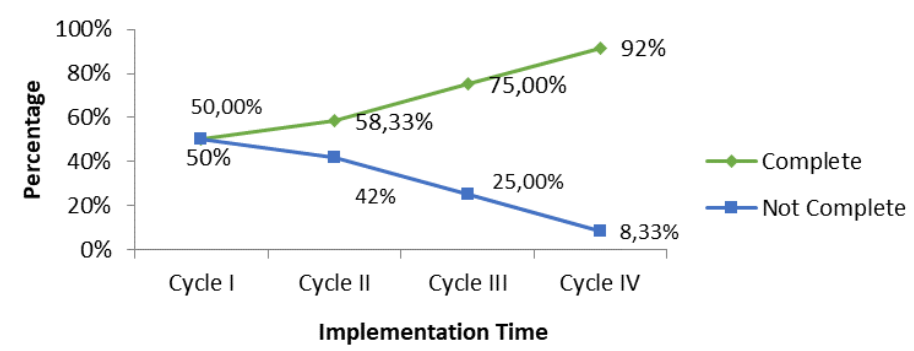

Fig. 3. Comparison of Student Learning Outcomes Cycle I, II, III and IV

Based on the indicators of completeness of learning outcomes that have been established that is a student is said to be successful or complete learning if it has reached the value of $\geq 63$ with classical completeness of at least $80 \%$. There are six people or $50 \%$ and students who do not complete; there are six people or $50 \%$. While in cycle II, there are seven people or $58.33 \%$ who complete it, and there are five people or $41.67 \%$ 
students who do not complete. In the third cycle, there are nine people or $75 \%$ of students who complete and there are three people or $25 \%$ of students who are not complete. In cycle IV, there are 11 people or $91.67 \%$ students who complete and there are one person or $8.33 \%$ students who are not complete. These results indicate that the completeness of student learning outcomes classically has exceeded the predetermined classical completeness indicator which is $80 \%$. The increase in the completeness of student learning outcomes in each of these cycles cannot be separated from the increased activity of teachers and students themselves, because of the increase in teacher activity and students, student learning outcomes also increase in each cycle. So that it can be concluded using the Problem Posing model combination Group Investigation and 3D Media can improve student learning outcomes. Based on the results of the study, the research is fulfilled until the fourth cycle.

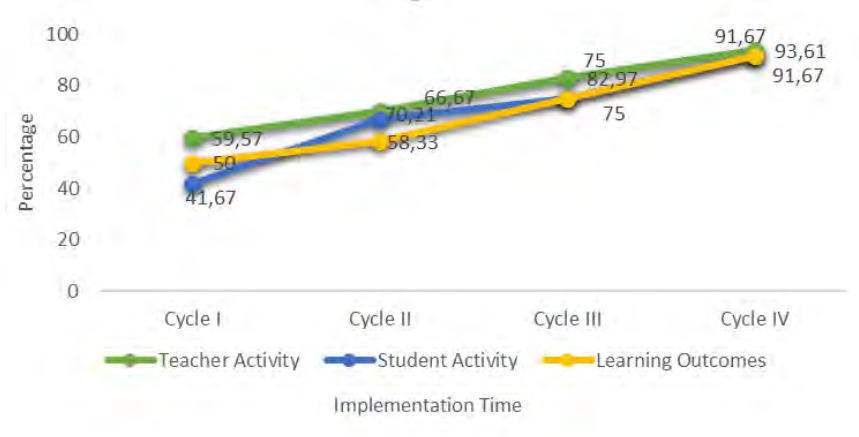

Fig. 4. All Aspect Trends

Can be seen in the graph above if the teacher's activity in the first cycle got a score of 59.57, in the second cycle got a score of 70.21, in the third cycle got a score of 82.97, and in the fourth cycle got a score of 93.61 .

In the activity of students in the first cycle, classical completeness reached $41.67 \%$, in cycle II classical completeness reached $66.67 \%$, in cycle III classical completeness reached $75 \%$ and cycle IV classical completeness reached $91.67 \%$.

On student learning outcomes for classical cycle completeness reached $50 \%$, for cycle II classical completeness reached $58.33 \%$, for cycle III classical completeness reached $75 \%$, and classical completeness IV reached $91.67 \%$.

The better the teacher's activity in guiding, organizing and designing learning activities that support the creation of effective learning processes, the impact on student activities and learning outcomes will also increase. The learning done by the teacher in the above learning was also caused by the improvements that the teacher had made at the next meeting. This is because after the learning activities the teacher performs self-reflection which is assisted by the observer's direction so that there is an increase in teaching activities at each stage in the learning activities from cycle I to cycle IV. This fact is supported by the opinion of [7] that the quality of education will increase if teachers are qualified and able to carry out the learning process. If the teacher has competence and quality, is capable and skilled in utilizing the means of learning, then quality education is realized as expected by many parties.

The cooperative learning system, teachers are required to be able to create a learning atmosphere that encourages students to feel that they need each other because the teacher always strives to improve the quality of learning by using the right cooperative model. The use of the right cooperative model can increase student activity both in the overall learning activities and student activities in the group and can improve student learning outcomes because the success of teachers in learning activities will support students' success in learning.

Increased student activity at each meeting initially only a few were very active and active, but at the last meeting, almost all the students got very active and active criteria. This shows that the Problem Posing model combination Group Investigation and 3D Media makes students more enthusiastic in learning because students are directly involved in the learning process.

In this cooperative learning model, the teacher acts more as a facilitator that serves as a bridge to a higher understanding, with the student's notes. The teacher not only provides knowledge to students but also must build knowledge in his mind. Students have the opportunity to gain hands-on experience in applying their ideas; this is an opportunity for students to find and apply their ideas [8].

Based on the data exposure, it can be seen that at each meeting there is an increase in student learning outcomes. The increase in improvement can occur due to increased teacher activity and also student activities where teachers and students play an important role in determining the success of learning outcomes. Teacher activity increases because there has been an improvement in the teacher's ability to control the class and teacher perseverance which is more active in guiding students in participating in learning, therefore, student activity becomes more increased. With the increase in student activity, the students' learning outcomes will also increase.

Improved learning outcomes are also due to the better learning process designed and implemented by the teacher so that students better understand the material provided. Classical student learning completeness has increased at each meeting. This indicates that learning by using the Problem Posing model combination of Group Investigation and 3D Media can improve student learning outcomes. The use of a combination of the three models can improve student learning outcomes because students do not only listen to what is explained by the teacher, but also the students can be active in solving problems and practice them directly or the students themselves who experience, collaborate in their groups, express their opinions to solve the proposed problem. The students are not only trained to be independent but also think critically and actively in solving the problems they face.

\section{CONCLUSION}

The conclusion of the research that has been done is teacher activity, student activity, and student learning outcomes in implementing learning by applying the Problem posing model combination Group Investigation and 3D Media on 
Mathematics in the nature of space in class V SDN Banua Anyar 4 Banjarmasin has been implemented with very good, very active, and achieving predetermined success indicators.

Based on the results of the conclusions above, some suggestions are as follows:

It is expected that the principal can be used as a consideration for input to the teacher to use the Problem Posing model combination Group Investigation and 3D Media as one of the alternatives used in mathematics learning, especially in the material properties of space to improve the quality of learning processes and outcomes.

To the teacher who experienced the same problem in teaching mathematics learning is expected to be a Problem Posing model combination Group Investigation and 3D Media as an alternative solution in improving the learning process, especially in the material properties of space to improve student learning outcomes and student activities in learning.

To other researchers who want to conduct classroom action research, especially those using the Problem Posing model, a combination of Group Investigation and 3D Media as input/reference material and the basis for further research development.

\section{REFERENCES}

[1] Heruman, Model pembelajaran matematika di sekolah dasar. Bandung: Remaja Rosdakarya, 2013.

[2] M. Huda, Model-model pengajaran dan pembelajaran. Yogyakarta: Pustaka Pelajar, 2014.

[3] A. Shoimin, 68 Model pembelajaran inovatif dalam kurikulum 2013. Yogyakarta: Ar-Ruzz Media, 2014.

[4] Y. Miarso, Menyemai benih teknologi pendidikan. Jakarta: . Jakarta: Pustekkom DIKNAS, 2014.

[5] Ghony and Almansyur, Metodologi penelitian kualitatif. Jakarta: ArRuzz Media, 2012.

[6] W. Sanjaya, Penelitian tindakan kelas. Jakarta: Pranadamedia Group, 2015.

[7] Isjoni, Cooperative learning efektifitas pembelajaran kelompok. Bandung: Alfabeta, 2012.

[8] Rusman, Model-model pembelajaran mengembangkan profesionalisme Guru. Jakarta: PT Raja Grafindo Utama, 2014. 